\title{
Islamophobia in America: The Anatomy of Intolerance
}

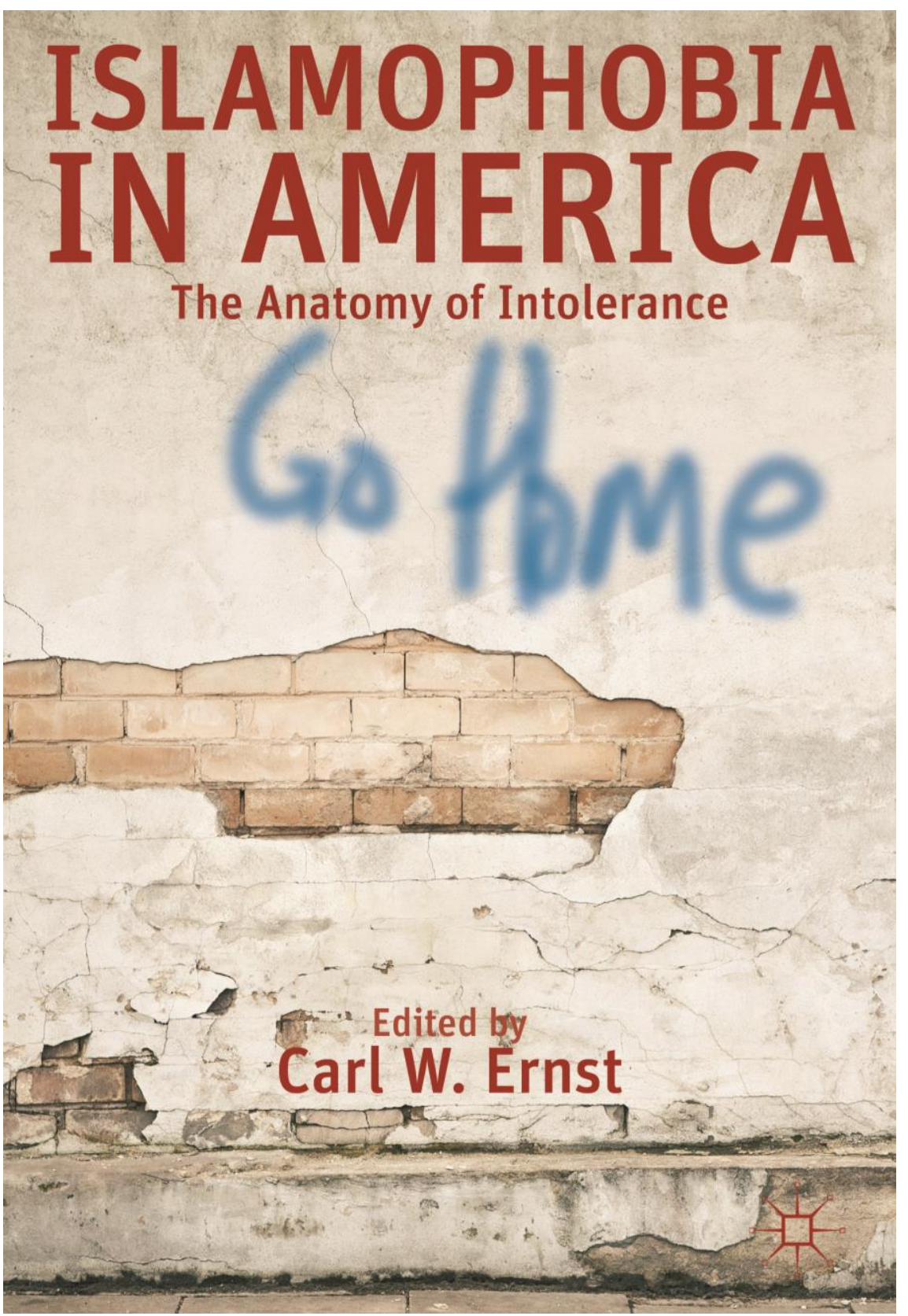

\section{Editor}

\section{Carl W. ERNST}

University of North Carolina at Chapel Hill, UNITED STATES 


\author{
Reviewer \\ Scott L. WALKER \\ Northwest Vista College, UNITED STATES
}

Publisher: Palgrave Macmillan

Publication Year: 2013

\title{
Edition: First Edition Pages: 212 Price: US\$29, €26 ISBN: 9781137321886
}

Islamophobia, a form of "othering" that is a potential topic of study in post-secondary cultural geography classes, has a long history in the United States and Europe. It is a substantially complex topic to understand, especially for those with no personal experience with Islam. Yet it is through "shallow and sensationalist journalistic accounts" (Hammer \& Safi, 2013, p. 9) that many people obtain their information about Islam and Muslims. Considerable understanding of socio-cultural values, negative social out-group attitudes, bigotry, xenophobia, and nationalism are some of the factors contributing to what might be termed the new racism of this century. Carl W. Ernst has edited an easy to follow, yet substantive, book of five chapters by six authors that spans the history of Islamophobia to gendered Islamophobia, to potential solutions for dealing with issues of Islamophobia as found in Detroit, Michigan. Contributing Anthropology Professor Andrew Shryock posits his perspective that Islamophobia is more than fear and hatred of Muslims; rather it is grounded in the vagueness of our hegemonic models of what it means to be an American and how our national identities are formed (2013). While this book is America-centric, which in this case is in reference to the United States of America, the history of Islam and international comparisons throughout make it worthwhile for any of us striving to teach for an understanding of what cultural geography is and how mixophobia creates the nature of the places in which we live (Anderson, 2010).

Americans and Britons have a shared history of fear and loathing of Muslims. In the seventeenth and early eighteenth centuries the English, who dominated the world in slave trade (Alford, 1977), trafficked African slaves to the American colonies, however, much of that population was unaware that Muslims even existed within the colonies themselves. The Anglo-American population at the time had little, if any, direct contact with slaves and the presence of Muslims went unobserved. Mahometans, a derogatory reference to Muslims of the time, were primarily used as a rhetorical tool in early America. In fact, the socially and politically influential Puritan minister Cotton Mather has been quoted as saying the colonies had "never had (that I ever heard of) one Mahometan breathing in it" (Kidd, 2009, p. 1), as if the American colonies were some sort of Christian utopia. Muslims were representative of an abhorrent out group and often served as rhetorical test cases in many political debates of the time, including whether or not there should be a religious test for presidential candidates. In 1788, in a strong break from British political-religious tradition and intolerance, debates aimed at ratifying the United States' Constitution led to the end of 
ideas of a religious test for the federal government's highest position - it "necessitated a new emphasis on the individual citizen bound by a common loyalty to the new Constitution, as demonstrated by a civic oath" (Spellberg, 2006, p. 486)-Muslims and Papists were targeted as the test cases. No one at the time could conceive of a Muslim or Catholic ever becoming a United States President.

In the second chapter of Islamophobia in America, Gottschalk and Greenburg go on to outline how the abstract and hypothetical American Muslim of the 1700s and 1800s served as a social extreme in order to influence political arguments because no "actual Muslim presence" (2013, p. 29) was ever expected in the U.S. As Cotton Mather had previously noted, they basically did not exist in America. Nevertheless, negative stereotypes of Muslims were reinforced by the British after the 1857 Indian rebellion thought to have been instigated by Indian Muslims. Later, British colonialism fueled Muslim anti-imperialism through the 1930s when the Pakistan movement called for a separate Muslim homeland. Likewise, the resistance of Muslims to convert to Christianity confounded many Christian missionaries, one of whom suggested that Muslims "regard themselves as God's peculiar people, and look with feelings of hatred and contempt upon all opposing religions" (American Board, 1850, p. 350). Apparently the irony was lost on this missionary author. He went on to write that the Mohammedans "have much more courage than the Hindoos, are much less mild and gentle..." (p. 349) and they "constitute a difficult, and, hitherto a comparatively unfruitful field...noted for intolerance, self-righteousness, and blind, unreasoning confidence in their own system" (p. 350). Muslim anti-colonialist views combined with a resistance to convert to Christianity were factors that intertwined with others to form British and American perspectives of Islam that persist even today. Conversely, modern polemics toward Muslims in America appear to be grounded in a consistently redefining American national identity in a mosaic nation with a penchant for cultural homogeneity where Islam is perceived to stand in contrast to the "American way" (Hammer \& Safi, 2013; GhaneaBassiri, 2013). In the post-secondary education classroom there is time and space to look more closely at and to discuss the multifaceted and complex causes of today's anti-Muslim bigotry in order to circumvent the endless 24-hour media loop where violence is regarded as newsworthy and certain audiences turn to that same media to explain what they see and hear in the media itself. The only view of Islam for many Americans is that of media-portrayed insecurity, violence, and unfounded fear designed to attract large audiences.

What is more, in his chapter in Islamophobia in America, GhaneaBassiri (2013) outlines another cultural loop, the manner in which a nation's deterioration of trust in its democratic institutions leads to the disintegration of human rights. He notes, "democratic processes" such as courts, elections, and constitutions, where everyone should have equal rights and be involved in the political process, do "not forge a cohesive national identity" (p. 60) in that questions of belonging and loyalty of minorities, religious or otherwise, pose an internal threat to American ideals and social order. Those in the minority become a pariah as the collective enemy masking "the real sources of political and social instability and 
discontent" (p. 62). This has been the case with Catholics in America between the 1850s and 1920s and Jews between the 1880s and 1920s. The lesson is that patterns of bigotry and prejudice are as American as baseball and apple pie as outlined in the modern history of the United States where undesirable values are attributed to out groups in the building of a national unity. This notion is overt in such examples as the swearing in of United States Congressman Keith Ellison, who is Muslim. He chose to be ceremoniously sworn in to office using Thomas Jefferson's copy of the Qur'an rather than the Bible. He was attacked by fellow congressman Virgil Goode who stated, "... if American citizens don't wake up and adopt the Virgil Goode position on immigration, there will likely be many more Muslims elected to office and demanding the use of the Koran" (Goldfarb, 2006, 2). Conflating immigration with Islam, Goode went on to state, "I fear that in the next century we will have many more Muslims in the United States if we do not adopt the strict immigration policies that I believe are necessary to preserve the values and beliefs traditional to the United States of America" (Goldfarb, 2006, 6). Ellison's response was civil: "I'm not an immigrant, I'm an African-American" (Swarns, 2006, 7).

In the 1920s and 1930s Black Americans formed the Moorish Science Temple of America (MSTA) and the Nation of Islam (NOI) predominantly in question of whether or not the United States was the correct object of Black American's allegiance. In a challenge to their second class citizenship, white supremacy movements, and terrorism of the prominent $\mathrm{Ku}$ Klux Klan these groups encouraged Black Americans to convert to Islam as a new national identity - simultaneously a religious and political movement (Curtis, 2013a, 2013b). While the Arabic and North African immigrant Muslims were well educated, fluent in multiple languages and considered white by many standards, indigenous Black Muslims were gaining the attention of the nascent Federal Bureau of Investigation (FBI) as political radicals. However, it was during the run up to World War II that FBI director J. Edgar Hoover attempted to ferret out anyone disloyal to the United States. A prime target became African American Muslims with any hint of political dissent or anti-American ideologies. Curtis (2013a) outlines this time frame well in his chapter in Islamophobia in America. He goes on to explain the "Black Muslim Scare of the 1960s" (p. 94), where the United States Department of Justice, realizing the First Amendment rights of Americans to have the free exercise of religion could only be circumvented by labeling Black American Muslim groups as cults that were covers for political organizations. Real Muslims were immigrant Muslims as purported by the FBI and the media. The real Muslims demonstrated the epitome of American values later during the height of the Cold War because religious expression by the real Muslims, immigrant or not, was an expression of American freedom, unlike the imagined repression of religion in the Soviet Union. Meanwhile, Black American Muslims were characterized as "having betrayed their real black heritage; they were deluded fakes" (Curtis, 2013a, p. 97). Thus, as presented by Curtis, "Islamophobia was not an ignorant reaction of the public to the presence of Muslims in America. It was manufactured" (2013a, p. 99). 
In a shift from historical Islamophobia to gendered Islamophobia, Juliane Hammer outlines the complexities of Islamophobia directed toward Muslim women in America. She makes the case that gender, as a social construct, is portrayed as Muslim men being vicious terrorists and Muslim women being subjugated by Muslim men; thus the need for Muslim women to be liberated from their own religion and culture. However, Muslim women have not always been portrayed as dominated by their religion, culture, or men. For instance, in the literature and stage of the Italian Renaissance for Muslim women "textually no preference is shown for Muslim or European [women]" (Kahf, 1999, p. 63). Gender limitations between European and Muslim women were equally and interreligiously a part of their patriarchal Mediterranean culture (Kahf, 1999). Although the dominant narrative of Muslim woman from the eighteenth century through today is one of female oppression, prior discourse from "Algiers to the Alps" has been one that is a "shifting, contingent, heterogeneous jumble" (Kahf, 1999, p. 176). What is evident in Hammer's chapter, Center Stage: Gendered Islamophobia and Muslim Women, is that the "jumble" continues today in America. The predominant threat to Muslim women in America today is not a repression through religious doctrine, nor is it liberal (or conservative) feminists trying to rescue the oppressed, rather, it is "unprovoked attacks in public places by bigoted strangers" (Hammer, 2013, p. 117).

Unprovoked attacks, hate crimes, bigotry, xenophobia, and other misaligned beliefs promote Islamophobia. In the final chapter of Islamophobia in America, Shryock labels Islamophobia as "symptomatic of our inability...to let Muslims take part in the construction of national identity" (2013, p. 146). He is not only referring to Islamophobia in the United States, but also to that found in other non-Muslim places such as Switzerland, France, England, and even that found where there is sharp contention between Islam and secularism such as in Nigeria, India, Pakistan, Egypt, and Turkey. Through our inability to let Muslims take part in what has become a hotly challenged form of Americanism, enormous governmental agencies have been produced and the United States' relationships with other countries has been altered. "Understanding how these processes work is one of the most important social issues of our day" (p. 168). A book like Islamophobia in America, that in reality places American Islamophobia in a greater historical and global context beyond just the United States, is prime for college and university students to study in order to grapple with the increasingly intersecting connections "that are endlessly contested, and are worth contesting, because they are shared" (Shryock, 2013, p. 169).

\section{References}

Alford, T. (1977). Prince among slaves. New York: Harcourt, Brace, Jovanovich.

American Board of Commissioners for Foreign Missions (ABCFM). (1850). Bombay: Letter from Mr. Hume, June 22, 1850. The Missionary Herald, 46(9), 289-406.

Anderson, J. (2010). Understanding cultural geography: Places and traces. London: Routledge. 
Curtis, E. E. (2013a). The Black Muslim scare of the Twentieth Century: The history of state Islamophobia and its post 9/11 variations. In C. W. Ernst (Ed.), Islamophobia in America: The anatomy of intolerance (pp. 75-106). New York: Palgrave MacMillan.

Curtis, E. E. (2013b). The study of American Muslims: A history. In J. Hammer \& O. Safi (Eds.), The Cambridge companion to American Islam (pp. 15-27). New York: Cambridge University Press.

GhaneaBassiri, K. (2013). Islamophobia and American history: Religious stereotyping and out-grouping of Muslims in the United States. In C. W. Ernst (Ed.), Islamophobia in America: The anatomy of intolerance (pp. 53-74). New York: Palgrave MacMillan.

Goldfarb, Z. A. (2006, December 21). Va. lawmaker's remarks on Muslims criticized. Washington Post. Retrieved from http://www.washingtonpost.com/wpdyn/content/article/2006/12/20/AR2006122001318.html

Gottschalk, P., \& Greenberg, G. (2013). Common heritage, uncommon fear: Islamophobia in the United States and British India, 1687-1947. In C. W. Ernst (Ed.), Islamophobia in America: The anatomy of intolerance (pp. 21-51). New York: Palgrave MacMillan.

Hammer, J., \& Safi, O. (2013). Introduction: American Islam, Muslim Americans, and the American experiment. In J. Hammer \& O. Safi (Eds.), The Cambridge companion to American Islam (pp. 1-14). New York: Cambridge University Press.

Kahf, M. (1999). Western representations of the Muslim woman: From Termagant to Odalisque. Austin, TX: University of Texas Press.

Kidd, T. S. (2009). American Christians and Islam: Evangelical culture and Muslims from the colonial period to the age of terrorism. Princeton, NJ: Princeton University Press.

Shryock, A. J. (2013). Attack of the Islamophobes: Religious war (and peace) in Arab/Muslim Detroit. In C. W. Ernst (Ed.), Islamophobia in America: The anatomy of intolerance (pp. 145-174). New York: Palgrave MacMillan.

Spellberg, D. A. (2006). Could a Muslim be President? An eighteenth-century Constitutional debate. Eighteenth-Century Studies, 39(4), 485-506.

Swarns, R. L. (2006, December 21). Congressman criticizes election of Muslim. New York Times. Retrieved from http://www.nytimes.com/2006/12/21/us/21koran.html?_r=1\& 